\title{
Agro-biological and economic efficiency in a beetroot (Beta vulgaris L.) production system fertilized with hairy woodrose (Merremia aegyptia (L.) Urb.) as green manure
}

\author{
Italo Nunes Silva, Francisco Bezerra Neto, Aurélio Paes Barros Júnior*, Jailma Suerda Silva de Lima, \\ Aridênia Peixoto Chaves, Renato Leandro Costa Nunes ${ }^{1}$, Hamurábi Anizio Lins, José Ricardo Tavares de \\ Albuquerque
}

\author{
Universidade Federal Rural do Semi-Árido, Centro de Ciências Vegetais, Departamento de Ciências Agronômicas e \\ Florestais, Av. Francisco Mota, 572, Costa e Silva, CEP 59625-900, Mossoró, RN, Brazil
}

*Corresponding author: aurelio.barros@ufersa.edu.br

\begin{abstract}
Beetroot (Beta vulgaris L.) is a tuberous vegetable that is under experimentation in the vegetable production system in Rio Grande do Norte state (Brazil). It is quite demanding, in nutritional terms. One of the alternatives to meet this need is green manuring using spontaneous species of the Caatinga biome. The aim of the present work was to optimize the agro-biological performance and economic profitability of the beetroot 'Early Wonder', fertilized with different doses of hairy woodrose (Merremia aegyptia (L.) Urb.) in this semi-arid environment. Hairy woodrose is a spontaneous species of the Caatinga biome that is widely distributed, being found in forests, fences, forest clearings and fields, growing in soils of different textures, producing biomass with a high content of macronutrients. This material was collected from spontaneous vegetation, native to the region, and used as green manure.The experimental design was a randomized complete block, with four treatments and five replicates. The treatments consisted of four amounts of hairy woodrose biomass incorporated into the soil $\left(10,25,40\right.$ and $55 \mathrm{t} \mathrm{ha}^{-1}$ of dry matter). The following agronomic characteristics were evaluated in each beetroot treatment: plant height, fresh mass of shoots, number of leaves per plant, dry mass of shoots and dry mass of roots, total and commercial root productivity, and root productivity classified into scrap and extra roots, extra A roots, extra AA and great roots. Apart from these characteristics, the following economic indicators were also determined for each treatment: gross income, net income, rate of return and profit margin. The maximum agro-biological efficiency of beet root productivity $\left(22.68 \mathrm{t} \mathrm{ha}^{-1}\right)$ was obtained from $44.92 \mathrm{t} \mathrm{ha}^{-1}$ of hairy woodrose biomass added to the soil. The maximum economic efficiency of the yield of beet roots was achieved as a net income of AU\$2,491.00 (R\$6,406.36) ha 1 , provided by the production of $22.04 \mathrm{t} \mathrm{ha}^{-1}$ of commercial roots, using $37.03 \mathrm{t} \mathrm{ha}^{-1}$ of hairy woodrose biomass incorporated into the soil. The use of hairy woodrose as green manure presents agro-economic feasibility in beet cultivation in this semi-arid environment.
\end{abstract}

Keywords: Beta vulgaris; Merremia aegyptia; beetroot; hairy woodrose; organic manure; semi-arid productivity.

Abbreviations: AU\$_Australian dollar; EC_electrical conductivity; GI_gross income; NI_net income; OM_organic matter; PM_profit margin; RR_rate of return; R\$_Brazilian real; TC_total costs.

Introduction

Beetroot is a tuberous vegetable with a high nutritional value, rich in iron, copper, zinc, manganese and vitamins B1, B2, B5 and C, and very useful in the formation of red blood cells (Souza et al., 2003); however, it is quite nutritionally demanding to grow. One of the viable ways to meet its nutritional needs is through green manuring, a cultivation practice whereby high-productivity plant remains of nutrient-rich biomass (Hodtke et al., 1999; Silva et al., 1999; Faria, 2004; Bezerra Neto et al., 2011), produced in situ or imported from other sites, are added to the soil in order to preserve, restore and increase the soil organic matter and nutrient contents (Batista et al., 2016).

It is known, however, that the effects of green manuring are quite variable, depending on the species used, the management given to the biomass, the time of planting and cutting of the manure, the time it resides in the soil, the soil and climatic conditions, and interactions between these factors (Alcântara et al., 2000). Beetroot is in the test phase of the vegetable production systems in the semi-arid land of northeastern Brazil. Studies aiming to improve the efficiency of these production systems, in terms of lowering their environmental impact, using green manures from spontaneous species of the Caatinga biome, have been carried out in the region (Linhares et al., 2012a; Silveira et al., 2012; Souza et al., 2015). Among the species that have been tested is the hairy woodrose, a spontaneous plant of the family Convolvulaceae that is native to northeastern Brazil. This has a green phytomass productivity of around 36 $\mathrm{t} \mathrm{ha}^{-1}$, with dry-matter nutrient contents of the order of $\mathrm{N}=$ $19.76 \mathrm{~g} \mathrm{~kg}^{-1}, \mathrm{P}=3.79 \mathrm{~g} \mathrm{~kg}^{-1}, \mathrm{~K}=34.28 \mathrm{~g} \mathrm{~kg}^{-1}, \mathrm{Ca}=8.93 \mathrm{~g} \mathrm{~kg}^{-1}$, 
$\mathrm{Mg}=5.0 \mathrm{~g} \mathrm{~kg}^{-1}, \mathrm{~S}=1.3 \mathrm{~g} \mathrm{~kg}^{-1}$ and $\mathrm{a} \mathrm{C} / \mathrm{N}$ ratio of 18:1, presenting as an excellent alternative for use as green manure (Bezerra Neto et al., 2011; Linhares et al., 2012b; Oliveira et al., 2017). Bezerra Neto et al. (2011), in studying the agronomic performance of lettuce as a function of different amounts of hairy woodrose incorporated into the soil, observed a higher productivity of lettuce leaf (10.26 t $\mathrm{ha}^{-1}$ ) from an amount of $6.11 \mathrm{t} \mathrm{ha}^{-1}$ of hairy woodrose added to the ground. This yield was higher by about 2.96 times than the yield obtained with lettuce $\left(3.47 \mathrm{t} \mathrm{ha}^{-1}\right)$ when not manured; that is, at a dose of $0 \mathrm{t} \mathrm{ha}^{-1}$ of green manure. On the other hand, Lima et al. (2008), in studying the agronomic performance of arugula (in terms of plant height, number of leaves per plant and yields of green and dry mass) using different types of fertilization, among them cattle manure, NPK mineral fertilizer, manuring with green hairy woodrose, and soil without fertilization, observed that the exclusive use of hairy woodrose, in the amount of $151 \mathrm{~g}$ per pot, provided the largest increases in all of the characteristics evaluated. In relation to green and dry mass yields of arugula, these increases were of the order of 2.36 and 1.44 times higher than those obtained in the control treatment (i.e., without fertilization). Linhares et al. (2011), in studying the agronomic performance of two arugula cultivars, Cultivada and Folha Larga, using different amounts of hairy woodrose in relation to soil without fertilization, observed higher yields of green mass (17.8 and $13.5 \mathrm{~g}$ per pot) in these cultivars, compared to the non-fertilized control treatment (13.9 and $11.1 \mathrm{~g}$ per pot). These yields were 1.28 and 1.22 times higher than those obtained in the control treatment. Oliveira et al. (2011), in studying the agronomic performance of carrot fertilized with different doses of hairy woodrose before sowing, verified that this green manure provided a $33 \%$ increase in the commercial productivity of carrot roots in relation to a lower incorporated dose of $5.4 \mathrm{t} \mathrm{ha}^{-1}$, and of $42 \%$ when compared to the non-fertilized control treatment. Vieira et al. (2018), in working the agronomic performance of cowpea-vegetable as a function of different amounts of roostertree biomass [Calotropis procera (Ait.) R.Br.] added to the soil, registered that the maximum economic efficiency of the green grain yield of cowpea was obtained for the net income of $R \$ 8,701.42$, provided by the production of $3.02 \mathrm{t}$ $\mathrm{ha}^{-1}$ of green grains, with the dose of $53.57 \mathrm{t} \mathrm{ha}^{-1}$ of roostertree biomass incorporated to the soil. On the other hand, Bezerra Neto al. (2013a), in intercropping carrot with cowpea-vegetable in the semiarid of northeastern Brazil fertilized with roostertree in different amounts of biomass, observed optimization of the commercial productivity of the carrot with the incorporation to the soil of $50.37 \mathrm{t} \mathrm{ha}^{-1}$ of the green manure. Due to a lack of data on green manuring in beetroot in a single production system, the aim of this work was to optimize the agro-biological performance and economic profitability of beetroot fertilized with different doses of hairy woodrose in the semi-arid region of Rio Grande do Norte state.

\section{Results and Discussion}

\section{Evaluation of agronomic characteristics}

Based on the results of regression analysis of the agronomic characteristics of plant height, fresh mass of shoots and dry mass of beetroots, evaluated as a function of biomass amounts of hairy woodrose, an ascending relationship between these characteristics and the growing amounts of biomass was observed (Fig. 1), reaching maximum values of $26.94 \mathrm{~cm}, 22.62$ and $4.63 \mathrm{t} \mathrm{ha}^{-1}$, respectively, in the amount of biomass of $55 \mathrm{t} \mathrm{ha}^{-1}$ of hairy woodrose added to the soil (Figs 1A, 1D).

This increase was obviously due to the greater availability of nutrients provided by the dynamics of green manure decomposition and mineralization, as well as the influence of organic fertilization on the improvement of soil fertility, through the promotion of biological activity in the soil, which favoured the solubilization of nutrients and, consequently, an increase in the root absorption surface (Batista et al., 2013; Martins et al., 2018).

These results may be due to an adequate supply of incorporated $\mathrm{N}$, thus promoting growth, vegetative development, expansion of the photosynthetic area, activation and an increase in crop production potential (Favacho et al., 2017). The plant material used, hairy woodrose, had a N and $\mathrm{K}$ content of 28.13 and $42.16 \mathrm{~g} \mathrm{~kg}^{-1}$, respectively, which provided a synchronization between nutrient release factors and the period of nutritional demand of the crop.

According to Prado (2009), N is one of the main nutrients responsible for the development of plants, as it directly influences cellular expansion and the photosynthetic rate, which are most demanded by vegetables.

A growth response in the plant height of beetroot has previously been observed by Silva et al. (2011), as a function of increasing doses of hairy woodrose incorporated into the soil, wherein a maximum height of $23.9 \mathrm{~cm}$ was reached in the amount of $15.6 \mathrm{t} \mathrm{ha}^{-1}$. The height increase between the lowest $\left(5.4 \mathrm{t} \mathrm{ha}^{-1}\right)$ and highest $\left(15.6 \mathrm{t} \mathrm{ha}^{-1}\right)$ hairy woodrose dose was of the order of $3 \mathrm{~cm}$. This result was lower than the one registered in this study, which was $5.7 \mathrm{~cm}$; this result is probably due to the low dosages used by Silva et al. (2011).

For the yields of fresh shoot mass and dry mass of beetroot, Silva et al. (2011) observed a growth response with increasing doses of hairy woodrose, where the yields of fresh and dry mass were of the order of 9.03 and $2.14 \mathrm{tha}^{-1}$, respectively, with $15.6 \mathrm{t} \mathrm{ha}^{-1}$ of green manure. These are lower than those obtained in this study, which were 22.68 and 4.63 , respectively, with a $55 \mathrm{t} \mathrm{ha}^{-1}$ dose of this manure incorporated.

In terms of number of leaves per plant, a stable number of 9.3 leaves was recorded up to an amount of hairy woodrose of $52 \mathrm{t} \mathrm{ha}^{-1}$, growing to 11 leaves per plant at a dose of $55 \mathrm{t}$ $\mathrm{ha}^{-1}$ of green manure (Fig. 1B).

Santos et al. (2017), in cultivating beets for two planting seasons in northeastern Brazil, in order to evaluate the effects of amounts of Calotropis procera biomass incorporated into the soil on the agronomic performance of 'Early Wonder' beet, observed that the number of leaves per plant increased linearly with increasing amounts of the green manure, reaching maximum values of 11.8 (autumn) and 9.88 (spring-summer) leaves per plant from $15.6 \mathrm{t} \mathrm{ha}^{-1}$ of $C$. procera.

Independently, the amount of green manure used, and the type of fertilizer, did not change the number of leaves per plant, leading to the conclusion that this is a characteristic of the cultivar used.

For the dry mass of beet shoots, a polynomial relationship between this characteristic and increasing amounts of the 
green manure biomass incorporated into the soil was recorded, reaching a maximum value of $0.49 \mathrm{t} \mathrm{ha}^{-1}$ from a biomass amount of $36.40 \mathrm{t} \mathrm{ha}^{-1}$, then decreasing to the final green manure biomass dosage (Fig. 1C).

In terms of the characteristics of the productivity of beetroot roots extra, extra $A$, extra $A A+$ great, total and commercial productivity of the beetroot, a polynomial relationship between these characteristics and increasing amounts of green manure biomass incorporated into the soil was also observed, reaching maximum values of $4.44,6.12,13.85$, 25.89 and $22.68 \mathrm{t} \mathrm{ha}^{-1}$, respectively, for the following amounts of hairy woodrose biomass added: $27.09,33.53$, $51.02,48.01$ and $44.92 \mathrm{t} \mathrm{ha}^{-1}$. This then decreased to the last applied amount of biomass (Figs 2A-D).

On the other hand, the productivity of scrap roots increased in tandem with increasing amounts of hairy woodrose biomass, reaching a maximum value of $3.50 \mathrm{t} \mathrm{ha}^{-1}$ in the last amount of green manure added to the soil (Fig. 2A).

A possible explanation for these yield characteristics is in the fact that hairy woodrose presents high nutrient values for $\mathrm{N}$, $\mathrm{K}$ and $\mathrm{Mg}\left(28.13 \mathrm{~g} \mathrm{~kg}^{-1} \mathrm{~N}, 42.16 \mathrm{~g} \mathrm{~kg}^{-1} \mathrm{~K}\right.$ and $2.70 \mathrm{~g} \mathrm{~kg}^{-1}$ of $\mathrm{Mg}$ ) in its composition. Another important factor in this high performance of hairy woodrose is its $C: N$ ratio of $18: 1$, which facilitates its rapid decomposition and release of nutrients (Batista et al., 2013).

This polynomial behaviour, and the optimization of each agronomic characteristic of the beet, can be attributed to the law of the maximum, where the excess of a nutrient in the soil from an increase in its dose can cause toxic effect and/or diminish the effectiveness of others, thus reducing the values of the analyzed variables (Almeida et al., 2015). Another justification that may be related to this behaviour and the optimization is the adequate synchrony between the period of greater nutrient demand by the beetroot and the release of the nutrients by the hairy woodrose (Fontanétti et al., 2006; Silva et al., 2017).

Souza et al. (2018), in studying the effect of green manure, using different amounts of hairy woodrose in beetroot intercropping with cowpea under the same conditions of semiaridity as this research, observed maximum values of $2.99,2.98,2.61,2.76,13.97,12.46$ and $1.64 \mathrm{tha}^{-1}$, respectively, for the dry mass of shoots, productivity of roots extra, extra A, extra AA + great, and for total and commercial root productivity when fertilized with the following respective amounts of hairy woodrose: $38.00,10.00,55.00$, $47.37,55.00,55.00$ and $10.00 \mathrm{t} \mathrm{ha}^{-1}$ added to the soil. These results were lower than those obtained in this research because the doses of green manure added to the soil were lower than those incorporated in this research. Only the dry mass of shoots was optimized, presenting the same quadratic behaviour of the characteristics evaluated above. Batista et al. (2016), by fertilizing beet with the green manures, roostertree and hairy woodrose, recorded that the best productive performance of the beetroot was reached in the total and commercial productivity of the roots at 18.74 , 16.33 and 17.57 , and $15.39 \mathrm{t} \mathrm{ha}^{-1}$. This productivity was also lower than those obtained in this study.

\section{Estimates of total costs and economic indicators}

From this study, the total costs of producing one hectare of beetroot in single cropping, fertilized with hairy woodrose, were calculated for each treatment using the tested amounts of the green manure, giving the following values: $\mathrm{R} \$ 14,618.36\left(10 \mathrm{t} \mathrm{ha}^{-1}\right), 16,820.16\left(25 \mathrm{t} \mathrm{ha}^{-1}\right), 18,996.71$ (40 $\left.\mathrm{t} \mathrm{ha}^{-1}\right)$ and 21,284.36 (55 tha $\left.\mathrm{th}^{-1}\right)$. With these costs, values of the economic indicators, calculated as gross income, net income, rate of return and profit margin, were, for each quantity: $R \$ 15,908.24 \mathrm{ha}^{-1}, \mathrm{R} \$ 1,289.88 \mathrm{ha}^{-1}, 1.09$ and $8.11 \%$ $\left(10 \mathrm{t} \mathrm{ha}{ }^{-1}\right) ; \mathrm{R} \$ 20,632.17 \mathrm{ha}^{-1}, \mathrm{R} \$ 3,812.01 \mathrm{ha}^{-1}, 1.23$ and 18.48\% (25 t ha ${ }^{-1}$ ); R\$25,077.01 ha ${ }^{-1}, \mathrm{R} \$ 6,080.29 \mathrm{ha}^{-1}, 1.32$ and $24.25 \%\left(40 \mathrm{t} \mathrm{ha}^{-1}\right)$, and $R \$ 23,828.84 \mathrm{ha}^{-1}, \mathrm{R} \$ 2,544.47 \mathrm{ha}$ ${ }^{1}, 1.12$ and $10.68 \%\left(55 \mathrm{t} \mathrm{ha}^{-1}\right)$, respectively (Table 1$)$.

In view of these results, it is worth noting that it is worthwhile to cultivate the tuberous beetroot, fertilized with hairy woodrose, since it provides a financial return compatible with the invested capital. Therefore, hairy woodrose becomes a good source of organic fertilizer for small producers, considering that this green manure is available spontaneously in the region where the study was conducted.

These results are in agreement with those obtained by Silva et al. (2011), in cultivating beetroot in monoculture, fertilized with hairy woodrose, and with those determined by Oliveira et al. (2011, 2012) and Bezerra Neto et al. (2014), in planting the tuberous vegetable carrot in sole crop, and intercropped with leafy coriander and arugula crops (Oliveira et al., 2017), both fertilized with hairy woodrose.

The economic indicators for the production system of beetroot in sole crop, as a function of the quantity of hairy woodrose biomass incorporated into the soil, were submitted to regression analysis, with the purpose of optimizing their agro-economic efficiencies. These presented a polynomial relationship (Fig. 3), with gross and net incomes, rate of return and profit margin increasing up to the maximum amounts of AU\$10,059.00 (R\$25,866.50) ha ${ }^{-1}$; $\mathrm{AU} \$ 2,491.31$ (R\$6,406.36) $\mathrm{ha}^{-1} ; 1.32$ and $26.17 \%$, respectively, in the following amounts of hairy woodrose incorporated biomass: 44.92, 37.03, 40.14 and $35.40 \mathrm{t} \mathrm{ha}^{-1}$, decreasing until the last added amount of the green manure (Figs 3A-D).

Among the economic indicators evaluated, net income is the indicator that allows the producer to visualize the best technology to be used in the process of beet production in sole crop, in terms of agroeconomic efficiency, since, according to Beltrão et al. (1984), net income better expresses economic value than gross income because the total costs of production are deducted from this. Thus, it can be inferred that a profit of $A \cup \$ 2,491.31(R \$ 6,406.36) \mathrm{ha}^{-1}$ can be obtained by adding $37.03 \mathrm{tha}^{-1}$ of hairy woodrose to the soil, due to the agronomic efficiency of the system being translated into economic terms.

Silva et al. (2011), in fertilizing a single crop of beetroot with hairy woodrose in the semi-arid state of Rio Grande do Norte, failed to optimize the economic efficiency indicators, obtaining an upward behaviour of these indicators with increasing amounts of hairy woodrose - behaviour in opposition to that obtained from this study. These conflicting results can be explained by the low dosages of hairy woodrose tested by the authors of that study. On the other hand, in a work carried out on the tuberous carrot intercropped with leafy coriander and arugula, Oliveira et al. (2017) reported a polynomial relationship, similar to that found in this study, between the economic indicators and the quantities of hairy woodrose tested, thus optimizing all indicators of economic efficiency. 
Table 1. Total costs, and the economic indicators of gross income, net income, rate of return and profit margin, of beetroot in single crop as a function of quantity of hairy woodrose incorporated to the soil.

\begin{tabular}{lccccc}
\hline $\begin{array}{l}\text { Amount of hairy woodrose tested } \\
\left(\mathrm{t} \mathrm{ha}^{-1}\right)\end{array}$ & \multicolumn{5}{c}{ Economic indicators } \\
\cline { 2 - 6 } & $\begin{array}{c}\text { Total costs } \\
\mathrm{R} \$ \text { ha }^{-1}\end{array}$ & $\begin{array}{c}\text { Gross income } \\
\mathrm{R} \$ \text { ha }^{-1}\end{array}$ & $\begin{array}{c}\text { Net income } \\
\mathrm{R} \$ \text { ha }^{-1}\end{array}$ & Rate of return & Profit margin (\%) \\
\hline 10 & $14,618.36$ & $15,908.24$ & $1,289.88$ & 1.09 & 8.11 \\
25 & $16,820.16$ & $20,632.17$ & $3,812.01$ & 1.23 & 18.47 \\
40 & $18,996.71$ & $25,077.01$ & $6,080.29$ & 1.32 & 24.25 \\
55 & $21,284.36$ & $23,828.84$ & $2,544.47$ & 1.12 & 10.68 \\
\hline
\end{tabular}
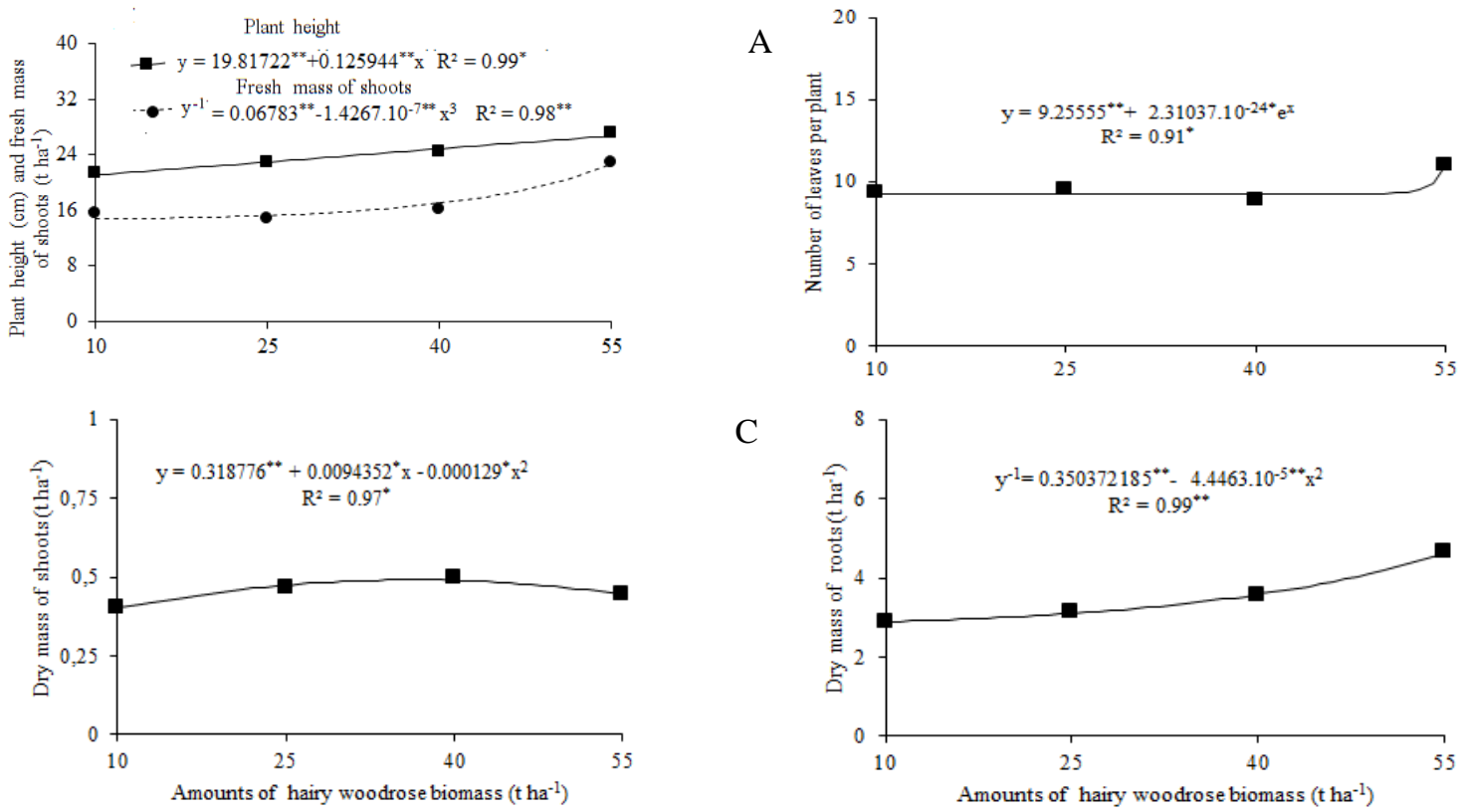

Fig 1. Response models for (A) plant height and fresh mass of shoots, (B) number of leaves per plant, (C) dry mass of shoots, and (D) dry mass of beet roots as a function of different amounts of hairy woodrose biomass incorporated into the soil.
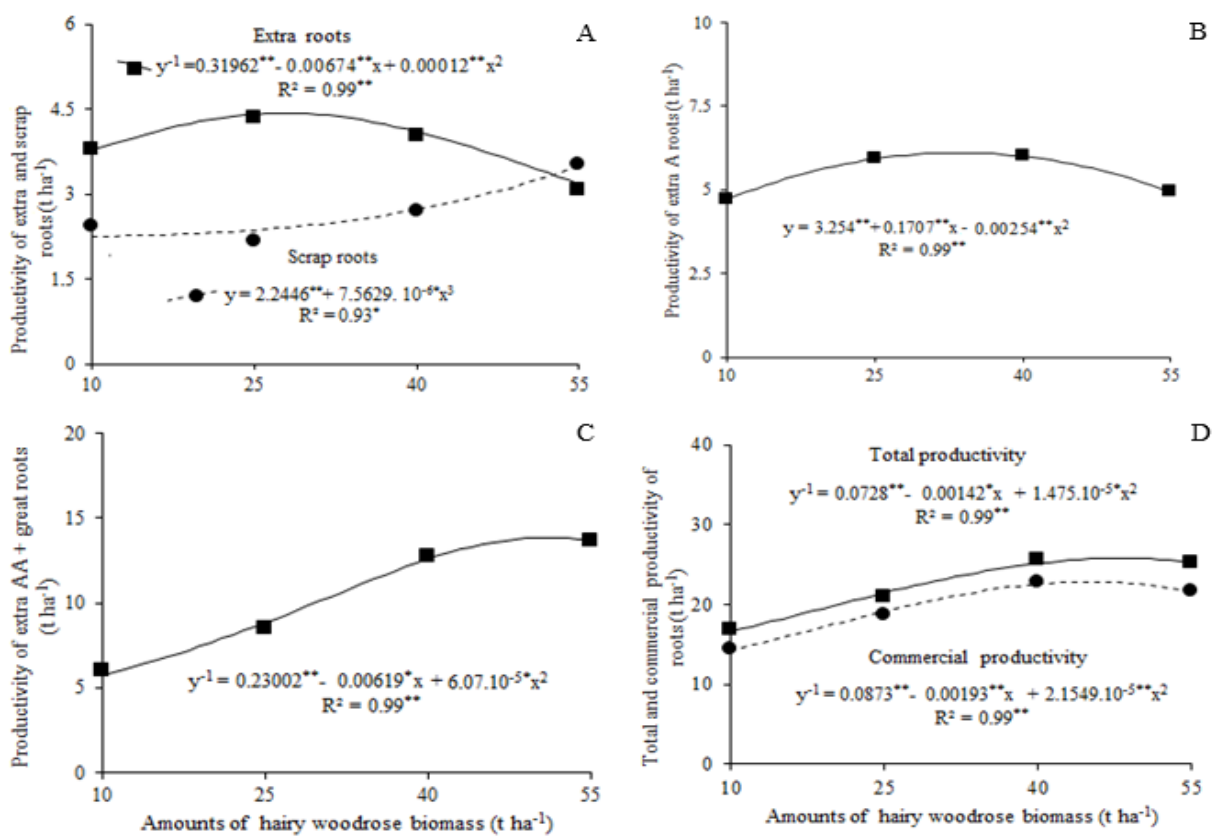

Fig 2. Response models for (A) productivity of extra and scrap roots, (B) extra A roots, (C) extra AA + great roots, and (D) total and commercial productivity of beet roots as a function of different amounts of hairy woodrose biomass incorporated into the soil. 

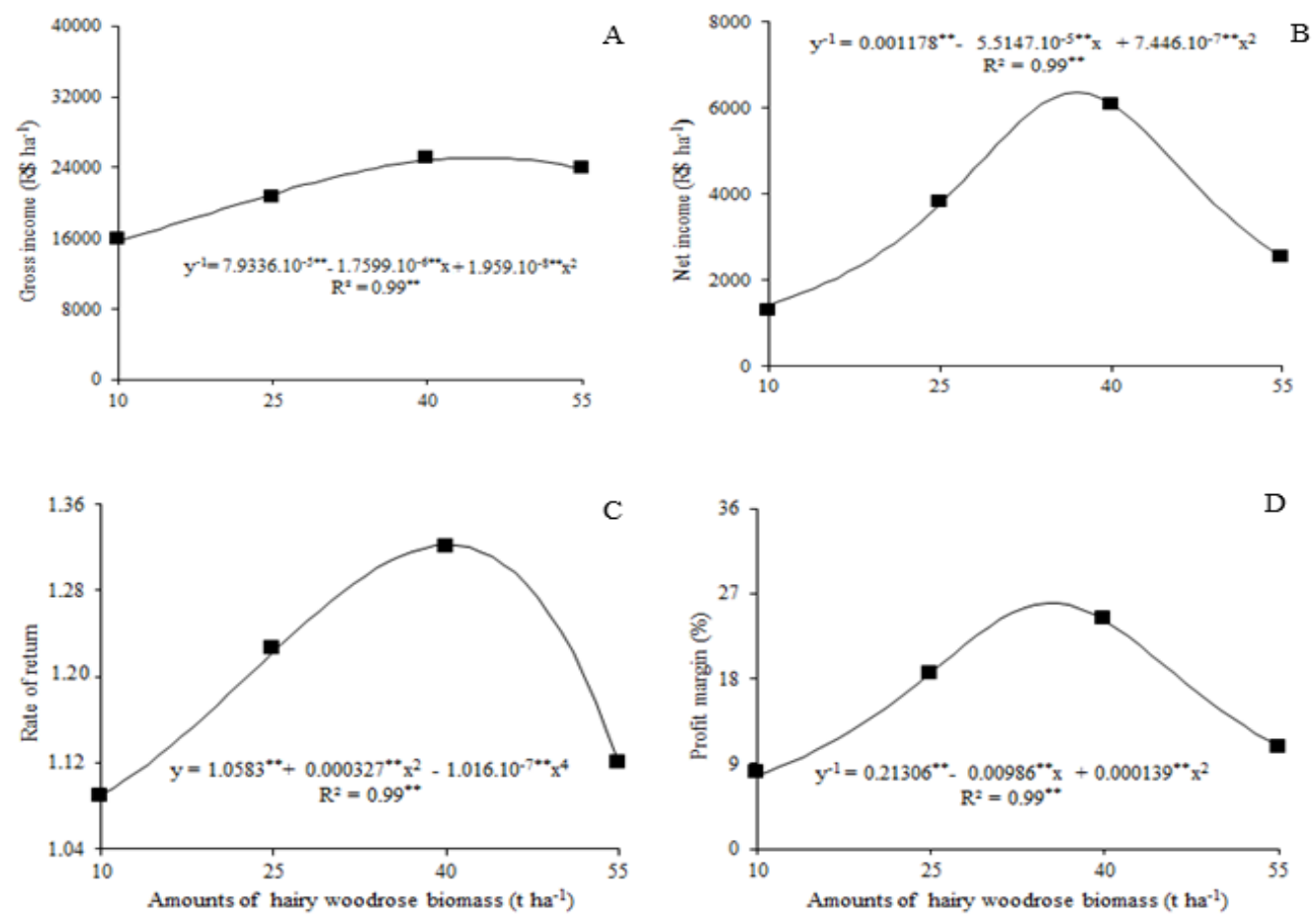

Fig 3. Response models for (A) gross income, (B) net income, (C) rate of return, and (D) profit margin of beetroot as a function of different amounts of hairy woodrose biomass incorporated into the soil.

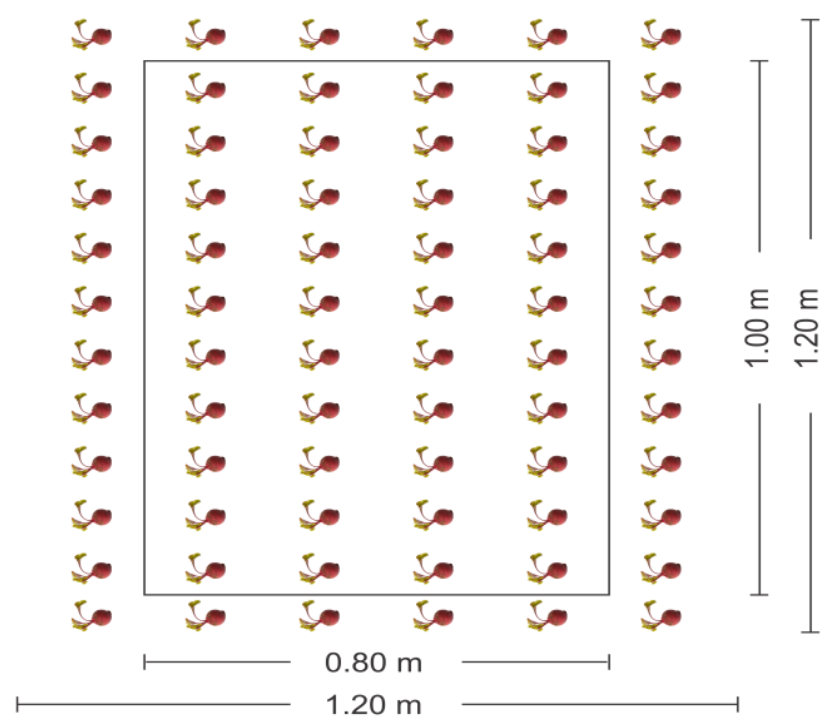

Fig 4. Detail of an experimental plot of beetroot in a single crop.

Silva et al. (2011), in cultivating beetroot with lettuce, fertilized with hairy woodrose to optimize the economic efficiency of the economic indicators, gross income, net profit, rate of return and profit margin, obtained results different from those observed in this study, with maximum values of $R \$ 25,440.00$ and $R \$ 18,093.00 \mathrm{ha}^{-1}, R \$ 3.46$ per real invested and $71.1 \%$, respectively, from $15.6 \mathrm{t} \mathrm{ha}^{-1}$ of hairy woodrose added to the soil. This quantity of hairy woodrose was smaller than those obtained in this work for gross income, net profit, rate of return and profit margin, which were of the order of 44.92, 37.03, 40.14 and $35.40 \mathrm{t} \mathrm{ha}^{-1}$ of hairy woodrose incorporated into the soil. This difference is due to the system of cultivation of the vegetables used.

\section{Materials and Methods}

\section{Research site}

The present study was conducted at the experimental farm 'Rafael Fernandes' of the Universidade Federal do SemiÁrido, in the Alagoinha district, $20 \mathrm{~km}$ from the municipality

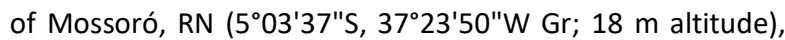
from July to October, 2012. The climate in this region, based 
on the Köppen classification, is BShw - dry and very hot, with two seasons: a dry season, which usually runs from June to January, and a rainy season, from February to May (Alvares et al., 2014). During the experimental period, the average temperature was $27^{\circ} \mathrm{C}$, minimum average temperature was $25^{\circ} \mathrm{C}$, maximum average temperature was $31^{\circ} \mathrm{C}$, mean relative humidity was $66 \%$, average wind speed was $4 \mathrm{~m} \mathrm{~s}^{-1}$, average radiation was $918 \mathrm{~kJ} \mathrm{~m}^{-2}$, rainfall was 0 $\mathrm{mm}$, average atmospheric pressure was $1011 \mathrm{hPa}$, and the average dew point temperature was $19^{\circ} \mathrm{C}$.

The research was carried out in a Eutrophic Red-Yellow Argisol. The chemical characteristics at a depth of 0-0.20 m, before installing the experiment, were: $\mathrm{pH}=6.80$;

$\mathrm{EC}=2.81 \mathrm{dS} \mathrm{m}^{-1} ; \mathrm{OM}=0.8125 \% ; \mathrm{P}=6.30 \mathrm{mg} \mathrm{dm}^{-3} ; \mathrm{K}=85.20$ $\mathrm{mg} \mathrm{dm}{ }^{-3} ; \mathrm{Ca}=2.01 \mathrm{cmol}_{\mathrm{c}} \mathrm{dm}^{-3} ; \mathrm{Mg}=1.09 \mathrm{cmol}_{\mathrm{c}} \mathrm{dm}^{-3} ; \mathrm{Na}=$ $35.90 \mathrm{mg} \mathrm{dm}{ }^{-3}$; sum of bases $=3.47 \mathrm{cmol}_{\mathrm{c}} \mathrm{dm}^{-3}$; and base saturation $=91 \%$. For this analysis, the soil chemical analysis methodology of EMBRAPA was used (EMBRAPA, 2009).

\section{Experimental procedure, treatments and plant material}

The experimental design was a randomized complete block with four treatments and five replications, where the treatments planned and tested were four quantities of hairy woodrose incorporated into the soil $\left(10,25,40\right.$ and $55 \mathrm{tha}^{-1}$ on a dry basis), previously predetermined, based on researches testing green manure amounts on other vegetable crops in the region (Oliveira et al., 2015; Bezerra Neto et al., 2013b), with the purpose of determining, through regression analysis, the optimum quantity to maximize the agronomic and economic efficiencies of beet production in sole crop. Each experimental plot had a total area of $1.44 \mathrm{~m}^{2}(1.20 \mathrm{~m} \times 1.20 \mathrm{~m})$, containing 72 beet plants, spaced $0.20 \mathrm{~m} \times 0.10 \mathrm{~m}$ apart. The harvest area of each plot (Linhares et al., 2017) was $0.80 \mathrm{~m}^{2}(1.00 \mathrm{~m} \times 0.80 \mathrm{~m})$, containing 40 beet plants (Fig. 4).

The hairy woodrose used as a green fertilizer in this study is a spontaneous plant that grows and develops naturally in the Brazilian Northeast Caatinga biome annually in the rainy season, and is widely distributed, being found in forests, fences, forest clearings and fields, growing and developing in soils of different textures (Lima et al., 2008). It is an annual herbaceous climbing plant, cylindrical, grooved, glabrous, or more commonly with yellowish hirsute pubescence. The leaves are yellowish, membranous and alternate, the inflorescence consists of bunches of six to nine flowers, similar to lilies, and the fruit is a subglobose capsule.

This plant yields $36 \mathrm{t} \mathrm{ha}^{-1}$ of green biomass. Five simple samples of this material were collected and transformed into a composite sample (Batista et al., 2016), which was sent to the Soil, Water and Plant Laboratory of the UFERSA to be analyzed. The results obtained were as follows: $\mathrm{N}=$ $28.13 \mathrm{~g} \mathrm{~kg}^{-1} ; \mathrm{P}=2.73 \mathrm{~g} \mathrm{~kg}^{-1} ; \mathrm{K}=42.16 \mathrm{~g} \mathrm{~kg}^{-1} ; \mathrm{Ca}=1.83 \mathrm{~g} \mathrm{~kg}^{-1}$; $\mathrm{Mg}=2.70 \mathrm{~g} \mathrm{~kg}^{-1} ; \mathrm{Fe}=79.5 \mathrm{mg} \mathrm{kg}^{-1} ; \mathrm{Zn}=16.66 \mathrm{mg} \mathrm{kg}^{-1} ; \mathrm{Cu}=$ $8.66 \mathrm{mg} \mathrm{kg}^{-1} ; \mathrm{Mn}=33 \mathrm{mg} \mathrm{kg}^{-1}$; and the $\mathrm{C}: \mathrm{N}$ ratio is $18: 1$. Based on these results, it can be observed that this plant is a good source of green manure for use in family farms that grow vegetables (Linhares et al., 2011). Its agronomic and economic efficiency has been proven in carrot (Bezerra Neto et al., 2014), arugula (Linhares et al., 2011) and lettuce (Góes et al., 2011).

The hairy woodrose for fertilization of the experimental plots was collected from several areas of native vegetation in the municipality of Mossoró, close to the research site, before it flowered in the rainy season, about 35 days before planting the experiment. The material was crushed in a forage machine into $2 \mathrm{~cm}$ pieces, dried in the shade for approximately five days until reaching the hay point (close to $10 \%$ humidity), quantified, and stored to be used prior to the experimental installation in the dry season.

\section{Management, cropping system and cultivar}

The soil in the research area was manually cleaned with the aid of a hoe, followed by a harrowing and lifting of the beds. Next, a solarization was performed as a pre-planting treatment, with transparent plastic of the type Vulca Brilho Bril Fles $(30 \mu \mathrm{m})$ laid for 40 days, to reduce nematodes, particularly Meloidogyne spp., and plant parasites in the top $0-10 \mathrm{~cm}$ of the soil.

The experimental plots were fertilized twice in the $0-20 \mathrm{~cm}$ soil layer. The first manuring used $40 \%$ of the relative amounts of each plot, 20 days before the beet planting. The remaining $60 \%$ was incorporated within 30 days of beet planting. Once the hairy woodrose was incorporated into the soil, irrigations were performed by micro-sprinkler twice a day (morning and evening), providing a water sheet of approximately $8 \mathrm{~mm} \mathrm{~d}^{-1}$ to promote microbial activity in the soil to aid the decomposition process. Weed control was done manually at 15 and 45 days after sowing.

The beet cultivar 'Early Wonder', adapted to cultivation in the northeast of the region, was planted 20 days after incorporation of the green manure into the soil, on 21 August, 2012, and thinning took place 16 days after planting. The beet was harvested on 29 October, 2011.

\section{Measured characteristics}

The beet was evaluated in a sample of 12 plants randomly removed from the harvest area, the height of the plants (measured with a ruler, from ground level to the end of the highest leaf, expressed in $\mathrm{cm}$ ), number of leaves per plant (obtained by counting), fresh mass (obtained by the weight of the shoots, expressed in $\mathrm{t} \mathrm{ha}^{-1}$ ), and dry mass of shoots (left in a greenhouse, with forced air circulation at $65^{\circ} \mathrm{C}$, until reaching constant mass weight, expressed in $\mathrm{t} \mathrm{ha}^{-1}$ ).

The total productivity of the roots was determined from the fresh root mass of the plants from the harvest area (expressed in $\mathrm{t} \mathrm{ha}^{-1}$ ), and the commercial productivity of the roots was obtained through the fresh root mass of the plants from the harvest area, free of cracks, bifurcations, nematodes and mechanical damage (expressed in $\mathrm{t} \mathrm{ha}^{-1}$ ). The dry mass of roots was measured from a sample of 12 plants, left in an oven until reaching constant mass weight (expressed in $\mathrm{t} \mathrm{ha}^{-1}$ ).

The classified productivity of the roots was determined by root diameter $(R D)$ classified into in extra $(R D>4$ and $<5 \mathrm{~cm}$ ), extra $A(R D \geq 5$ and $<6 \mathrm{~cm})$,; extra $A A(R D \geq 6$ and $<7 \mathrm{~cm})$ and great $(R D>7)$. All roots that were damaged, cracked, bifurcated and/or smaller than $4 \mathrm{~cm}$ in diameter were considered to be scrap (Horta et al., 2001).

Gross income (GI) from the tested treatments was obtained by the value of production per hectare $\left(R \$ \mathrm{ha}^{-1}\right)$, at a price $\left(\mathrm{R} \$ 1.10 \mathrm{~kg}^{-1}\right)$ paid to the producer at the market level in the region in December 2012. Net income (NI) was calculated by the following expression: $N I=G I-T C$, where TC (total 
costs of production) was the sum of all expenses (input and labour) in each treatment, expressed in $\mathrm{R} \$ \mathrm{ha}^{-1}$.

The rate of return (RR) was obtained by the expression: $R R=G I / T C$. The profit margin was obtained as the ratio of $\mathrm{NI}$ to $\mathrm{Gl}$, expressed as a percentage.

\section{Statistical analysis}

A univariate analysis of variance was used to evaluate the effects of the treatments on the variables, using the software, Sisvar (Ferreira, 2011). Three assumptions underlying the univariate analysis were tested. To test for additivity of the model, Tukey's test for nonadditivity was applied to yield residuals data for the variable. For each variable, a standard analysis of variance was constructed, and the error sum of squares was partitioned into two parts - additivity and residual. The homogeneity of variances was tested on the residual data of treatments by Bartlett $\chi^{2}$, ignoring block effects. A test for normality was performed using statistics W of Shapiro-Wilk (SAS Institute, 1995).

Thereafter, a response curve adjustment procedure for each characteristic, as a function of the amount of hairy woodrose used, was performed through the Table Curve software (Systat Software Inc., 2002). The response functions were evaluated based on the following criteria: significance of the error mean square of regression (EMSReg), high coefficient of determination $\left(R^{2}\right)$, and significance of regression parameters, using the $t$ test at 0.05 .

\section{Conclusions}

The maximum agro-biological efficiency of beetroot root productivity was obtained for a commercial root yield of $22.68 \mathrm{t} \mathrm{ha}^{-1}$, with $44.92 \mathrm{t} \mathrm{ha}^{-1}$ of hairy woodrose biomass added to the soil. The maximum economic efficiency of beetroot root yield was achieved by a net income of AU\$2,491.00 $(R \$ 6,406.00)$ ha $^{-1}$, provided by the production of $22.04 \mathrm{t} \mathrm{ha}^{-1}$ of commercial roots, with $37.03 \mathrm{t} \mathrm{ha}^{-1}$ of hairy woodrose biomass incorporated into the soil. The use of hairy woodrose as a green manure presents an agroeconomic feasibility for beetroot cultivation in the semiaridity of Rio Grande do Norte state. Cultivation in the fall resulted in a higher total and commercial productivity of the roots of beetroot fertilized with C. procera.

\section{Acknowledgements}

Special thanks are due to the Coordenação de Aperfeiçoamento de Pessoal de Nível Superior for their financial support of this work, and to the research group at the Crop Science Department of the Universidade Federal Rural do Semi-Árido, which develops technologies for growing vegetable crops on family farms.

\section{References}

Alcântara FA, Furtini Neto AE, Paula MB, Mesquita HA, Muniz JA (2000) Adubação verde na recuperação da fertilidade de um Latossolo Vermelho-Escuro degradado. Pesqui Agropecu Bras. 35:277-288.
Almeida AES, Bezerra Neto F, Costa LR, Silva ML, Lima JSS, Barros Júnior AP (2015) Eficiência agronômica do consórcio alface-rúcula fertilizado com flor-de-seda. Rev Caatinga. 28:79-85.

Alvares CA, Stape JL, Sentelhas PC, Gonçalves JL de M, Sparovek G (2014) Koppen's climate classification map for Brazil. Metereol Z. 22:711-728.

Batista MAV, Bezerra Neto F, Ambrosio MMQ, Guimarães LMS, Saraiva JPB, Silva ML (2013) Atributos microbiológicos do solo e produtividade de rabanete influenciados pelo uso de espécies espontâneas. Hortic Bras. 31:587-594.

Batista MAV, Bezerra Neto F, Silva ML, Ambrósio MMQ, Cunha JLXL (2016) Atributos de solo-planta e de produção de beterraba influenciados pela adubação com espécies da Caatinga. Hortic Bras. 34:12-19.

Batista TMV, Bezerra Neto F, Silva IN, Silva ML, Oliveira EQ, Barros Júnior AP (2016) Agronomic efficiency of the intercropping of arugula with carrot under different population combinations. Rev Caatinga. 29:76-84.

Beltrão NEM, Nóbrega LB, Azevedo DMP, Vieira DJ (1984) Comparação entre indicadores agroeconômicos de avaliação de agroecossistemas consorciados e solteiros envolvendo algodão upland e feijão "caupi". Campina Grande: CNPA, 21p. (Boletim de Pesquisa, 15).

Bezerra Neto F, Góes SB, Sá JR, Linhares PCF, Góes GB, Moreira JN (2011) Desempenho agronômico da alface em diferentes quantidades e tempos de decomposição de jitirana verde. Rev Bras Cienc Agrar. 6:236-242.

Bezerra Neto F, Oliveira LJ, Santos AP, Lima JSS, Silva IN (2014) Otimização agroeconômica da cenoura fertilizada com diferentes doses de jitirana. Rev Cienc Agron. 45:305311.

Bezerra Neto F, Silva ML, Vieira FA, Silva RCP (2013a) Performance produtiva de cenoura consorciada com caupi-hortaliça sob diferentes quantidades de flor-deseda. In: Congresso Nacional de Feijão-Caupi, 3, 2013. Anais...Recife: Instituto Agronômico de Pernambuco. 5p.

Bezerra Neto F, Silva ML, Vieira FA, Silva RCP, Silva IN (2013b) Consórcio de beterraba com caupi-hortaliça adubado com diferentes quantidades de flor-de-seda. In: Congresso Nacional de Feijão-Caupi, 3, 2013. Anais...Recife: Instituto Agronômico de Pernambuco. 4p.

Empresa Brasileira de Pesquisa Agropecuária - EMBRAPA (2009) Manual de análises químicas de solos, plantas e fertilizantes. 2a edição revisada e ampliada, EMBRAPA, Brasília. 627p.

Faria CMB de (2004) Comportamento de leguminosas para adubação verde no submédio São Francisco. Petrolina, PE: Embrapa Semi-Árido. 22p. (Boletim de Pesquisa).

Favacho FS, Lima JSS, Bezerra Neto F, Silva JN, Barros Júnior AP (2017) Eficiência produtiva e econômica do consórcio de cenoura $x$ caupi proveniente de adubação verde e arranjos espaciais. Rev Cienc Agron. 48:337-346.

Ferreira DF (2011) Sisvar: A computer statistical analysis system. Ciên e Agrotec. 35:1039-1042.

Fontanétti A, Carvalho GJ, Gomes LAA, Almeida K, Morais SRG, Teixeira CM (2006) Adubação verde na produção de alface americana e repolho. Hortic Bras. 24:146-150.

Góes SB, Bezerra Neto F, Sá JR, Linhares PCF, Góes GB, Moreira JN (2011) Productive performance of lettuce at different amounts and times of decomposition of dry scarlet starglory. Rev.Cienc. Agron. 42: 1036-1042. 
Hodtke M, Araujo PA, Kopke U, Almeida DL de (1999) Nutritional status, grain yield and $\mathrm{N}$-balance of organically grown maize intercropped with green manure. In: Foguelman D, Willie L (eds.) Organic agriculture: The credible solution for the XXI ${ }^{\text {st }}$ Century. Mar del Plata: IFOAM. p.135-141.

Horta ACS, Santos HS, Scapim CA, Callegari O (2001) Relação entre produção de beterraba, Beta vulgaris var. conditiva, e diferentes métodos de plantio. Acta Sci-Agron. 23:11231129.

Lima GKL, Linhares PCF, Bezerra Neto F, Paiva APM, Maracajá PB (2008) Uso de jitirana incorporada à adubação com esterco bovino na cultura da rúcula cv. Folha Larga. Rev Caatinga. 21:135-139.

Linhares PCA, Lima JSS, Bezerra Neto F, Rodrigues GSO, Chaves AP (2017) Polycultures of coriander, carrot, and arugula in strip-intercropping system. Rev Caatinga. 30:622-632.

Linhares PCF, Maracajá PB, Bezerra AKH, Pereira MFS, Paz AES da (2011) Rendimento de cultivares de rúcula adubado com diferentes doses de Merremia aegyptia L. Rev Caatinga. 6:7-12.

Linhares PCF, Pereira MFS, Assis JP, Bezerra AKH (2012b) Quantidades e tempos de decomposição da jitirana no desempenho agronômico do coentro. Ciên Rural. 42:243248.

Linhares PCF, Pereira MFS, Dias MAV, Bezerra AK, Moreira JC (2012a) Rendimento de coentro (Coriandrum sativum) em sistema de adubação verde com a planta jitirana (Merremia aegyptia). Rev Bras de Plantas Med. 14:143148.

Martins BNM, Souza EGF, Santos MG, Barboza M, Barros Júnior AP, Silveira, LM, Bezerra Neto $F$ (2018). Productivity and economic viability of carrot fertilized with Calotropis procera in different growing seasons. J Exp Agr Int. 20:113.

Oliveira LAA, Bezerra Neto F, Silva ML, Oliveira OFN, Lima JSS, Barros Júnior AP (2015) Viabilidade agronômica de policultivos de rúcula/cenoura/alface sob quantidades de flor-de-seda e densidades populacionais. Rev Caatinga. 28:116-126.

Oliveira L, Bezerra Neto F, Lima JSS, Oliveira EQ, Moreira JN, Silva IN (2017) Viability of polycultures of arugula-carrotcoriander fertilized with hairy woodrose under different population densities. Rev Bras Eng Agric Ambient. 21:611617.

Oliveira MKT, Bezerra Neto F, Barros Júnior AP, Lima JSSL, Moreira JN (2011) Desempenho agronômico da cenoura adubada com jitirana antes da sua semeadura. Rev Cienc Agron. 42: 364-372.
Oliveira MKT, Bezerra Neto F, Barros Júnior AP, Moreira JN, Sá JR, Linhares PCF (2012) Desempenho agroeconômico da cenoura adubada com jitirana (Merremia aegyptia). Hortic Bras. 30: 433-439.

Prado RM (2009) 500 Perguntas e respostas sobre nutrição de plantas. Jaboticabal: FCAV- GENPLANT. $108 \mathrm{p}$.

Santos MG dos, Souza EGF, Silva AFA da, Barboza M, Soares $E B$, Lins $H A$, Barros Júnior AP, Silveira LM da, Bezerra Neto, F (2017) Beetroot production using Calotropis procera as green manure in the Brazilian Northeast semiarid. Aust J Crop Sci. 11: 1268-1276.

Sas Institute (1995) SAS Statistical Package: version 6.12. SAS Inc., Cary.

Silva AFA, Souza EGF, Barros Junior AP, Bezerra Neto F, Silveira LM (2017) Agronomic performance in radish fertilised with Calotropis procera (Ait.) R. Br. in two growing seasons. Rev Ciên Agron. 48:328-336.

Silva FC da (1999) Manual de análises químicas de solos, plantas e fertilizantes. Brasília: Embrapa Comunicação para a Transferência de Tecnologia. 370p.

Silva ML, Bezerra Neto F, Linhares PCF, Sá JR, Lima JSS, Barros Júnior AP (2011). Produção de beterraba fertilizada com jitirana em diferentes doses e tempos de incorporação ao solo. Rev Bras Eng Agric Ambient. 15: 801809.

Silveira MA, Gomes MV, Santos SL, Sousa TP, Linhares PCF, Fernandes D (2012) Desempenho agronômico do coentro fertilizado com mata-pasto. Agropec Cien Semi-Árido. 8:55-59.

Sousa, DM de, Bezerra Neto F, Lima JSS de, Lima GKL de, Chaves AP, Silva JN da (2018) Agro-economic performance of the association of beet with green cowpea in different amounts of hairy woodrose. Rev Bras Eng Agric Ambient. 22:194-199.

Souza RJ, Fontanetti A, Fiorini CVA, Almeida K (2003) Cultura da beterraba: Cultivo convencional e cultivo orgânico. Lavras: UFLA. 37p.

Souza EGF, Barros Júnior AP, Bezerra Neto F, Silveira LM, Leal YH, Alves MJG (2015) Rentabilidade da rúcula fertilizada com biomassa de flor-de-seda em função da época de cultivo. Rev Caatinga. 28:65-77.

Systat Software (2002) Table curve 2D e 3D. Systat Software Inc., San Jose.

Vieira FA, Bezerra Neto F, Silva ML, Lima JSSL, Barros Júnior AP, Silva IN (2018) Technical-economic efficiency of the yield of green grains of cowpea fertilized with roostertree. Rev Caatinga. 31:504-510. 